\title{
Fragile State of Africa, Non-state Actors and COVID 19: Annual Assessment
}

\author{
Soumya Awasthi \\ School of International Studies, Jawaharlal Nehru University, New Delhi, India
}

Email address:

Soumyaawasthi27@gmail.com

\section{To cite this article:}

Soumya Awasthi. Fragile State of Africa, Non-state Actors and COVID 19: Annual Assessment. Journal of Family Medicine and Health Care. Vol. 7, No. 1, 2021, pp. 1-6. doi: 10.11648/j.jfmhc.20210701.11

Received: January 15, 2021; Accepted: February 17, 2021; Published: March 4, 2021

\begin{abstract}
With the end of year 2020, the international policy pundits have taken the annual assessment of post Covid-19 scenario across the globe. This paper aims at assessment of the Fragile state of Africa, which has been facing a double-edged sword. Africa has witnessed maximum attacks by the two groups affiliated to ISIS and Al Qaeda as well as significant number of Covid cases. The two most significant terror groups Boko Haram and Al Shabab have taken advantage of the pandemic to challenge the state authorities. Aim of this paper is to review the year 2020 and what has been its impact on the citizens of Africa, it also discusses the impact of natural calamity like locust attack which effects the food supply and demand cycle including its impact on food and nutrition. Due to high impact on the food and grains the grievances amongst the people have raised and this has been used as an opportunity by the non-state actors to attract more and more volunteers to join the group. Therefore, this paper will observe how the religiously inclined terror groups have argued the pandemic and asked its members to use the opportunity to the fullest and reach out to more and more people, carry out more and more attacks and kill as many infidels as possible. Due to such a rapid action and eventful period, it becomes vital to capture the highlights of the year and assess in order to prepare for next such natural disaster. The paper especially focuses on the Sahel Region of Africa.
\end{abstract}

Keywords: Sahel Region, Africa, Covid19, Boko Haram, Al Shabab, Food Security, Terrorism, Internally Displaced People (IDP)

\section{Introduction}

COVID-19 has eclipsed all vital policy driver. It has challenged the normative system all across the globe. While the powerful nations can sustain themselves, it is the small and fragile nations which are affected the most. The pandemic hit fragile states are facing double-edged swords, with Covid-19 adding fuel to the fire into the persisting security challenges.

The terror groups in the fragile states of Africa have recaptured the attention due to the ongoing humanitarian catastrophe. Moreover, because these rebels are using it as an opportunity for three R's; Recruit, Reclaim and Resources. The diversion of attention from security to containment of the virus has been utilised to attack and capturing of the resource-rich areas. Covid-19 has been the catalytic agent for the rise in the attacks by the Sunni Wahabi groups like Islamic States, Al-Qaeda, Boko Haram and Al-Shabab.

\section{Impact of the Status of the Virus in the Region}

The Secretary-General of World Health Organisation Antonio Guterres, in one of the press releases on May 20, 2020, stated: "still early days for the pandemic in Africa". [1] He mentioned that flood of Covid-19 is yet to arrive in Africa, and "the pandemic threatens African progress.

The World Health Organisation (WHO) has called on the African nations to increase their monitoring and treatment of the virus to detect any further mutation.

As per the latest data as on, so far there has been increase of 30 percent in weekly new cases total number of Covid cases. In Africa totals to 3,067,060 cases with 72,805 deaths. [2]

Zeroing down to Sahel region comprising of thirteen nations, the total number of confirmed Covid-19 cases are approximately 283,005, recoveries around 245,399 and 3,943 deaths. [3]

The majority Sunni-Wahabi Islamic rebel groups controlling 
the region are hindering the regional efforts by the international agencies. As a result, this could be a probable trigger point in future for the rise in the number of Covid cases.

\section{Terror Attacks in Africa}

According to African Centre for the Study and Research on Terrorism, Africa recorded total 195 terrorist attacks leading to 573 deaths by December 29, 2020. The five countries most affected by terrorist and violent extremist attacks during the period were: DRC, Somalia, Mali, Mozambique, and Nigeria.

While 122 out of the 195 terrorist attacks were launched against Civilians, 63 targeted Military / Security forces. Seven attacks targeted International Organizations and three attacks targeted Governmental Institutions / Officials. The two main terror groups which carried out these attacks are Boko Haram and Al-Shabab. They switch their allegiance from time to time between Islamic State and Al Qaeda. [4]

Apart from attacks in the most disturbed region in Africa, there has been several kidnappings and ethnic killings primarily to collect debts. Sometimes it also involves the exchange of cows, land and crops in return of the abducted family member. There was the killing of around 160 people from the Fluani tribe in Central Mali.

In Burkina Faso, one of the weakest link in the Sahel region the jihadi rebel groups attacked French-speaking schools were targeted for propagating Western culture. As a result, several teachers got murdered and several security forces people were attacked by the Group to Support Muslims and Muslims (GSIM), which had pledged allegiance to al Qaeda. [5]

The Mocimboa de Praia town in the northern part of Mozambique known for the Liquid Natural Gas fields is under the control of a newly formed jihadist group, the Islamic State Central African Province (ISCAP) affiliated to ISIS in Somalia.

There is also an upsurge of Islamic preachers from the bordering areas like Kenya, Congo, and Uganda. These preachers started interacting with the disenfranchised Muslim youth, and they formed an ultra-conservative radical Islam. They have been misinforming the people that Muslims are immune to the virus. Further, the group has started giving loans and sponsorships to these unemployed youths in the form of a charitable gesture to build trust. However, this comes with the condition that these Muslim youth will return for Islamic causes when the time comes.

In the Central African Republic (CAR), has witnessed conflict since early this year due to the fallout of the peace agreement between the government and 14 armed groups. The conflict led to the barricading of the economic transit route Bangui- Beloko road, causing food security issues. As of now, around 80 per cent of the CAR region is under the control of non-state actors from various factions and alliances.

Further, a coalition was formed by all the rebel group in CAR called Seleka, which comprises of majority Muslims from Chad and Sudan (Northern part of CAR). In response to this coalition, the Christians from Southern CAR region formed a rebel group called Anti-Balaka to counter Seleka group.

\section{Terror Groups, Ramadan and COVID-19}

The arrival of Covid-19 was soon followed by the holy month of Ramadan April 2020. It was one of the most followed events, unlike in the past, given the nature of the celebrations, which involves close congregational prayers and public gathering.

The UN Secretary-General António Guterres has argued that humankind faces a common enemy in COVID-19, and thus appealed for a "global ceasefire". [6]

However, the terror groups in Africa took advantage of the situation to advance their propaganda, objectives and stoke fear amongst the citizens in the name of religion. These groups supported the call of Islamic State in Iraq calling it the 'Battle of Ramadan'. [7] The Islamic State, al-Qaeda-linked groups, Boko Haram, Al-Shabab and other splinter rebel groups have exploited the Covid-19 scenario and successfully grafted itself in Maghreb, Somalia, Lake Chad Basin, Burkina Faso, Nigeria, Tanzania and Mozambique through its affiliates.

On average, terrorists killed about 28 people and injured an estimated 28 others during those three-weeks. There were an estimated 56 casualties, which include fatalities and injuries, each day. [8]

The 1,171 casualties (584 fatalities, 587 injuries) during the first three weeks of the holy month have already surpassed the 1,087 (531 fatalities, 556 injuries) [9] during the same period last year by about ten per cent. The figures are from the attacks carried out during the Ramadan period. [9]

\section{The 'Battle of Ramadan'}

In January, ISIS newsletter Al-Naba published that "a new disease spreads death and panic" in "communist China" for the torture done to the Uyghur Muslims. Furthermore, the newsletter said Iran suffered an outbreak, and the newsletter wallowed that the contagion was an exemplary punishment from God for Shiite Muslims "idolatry". [9]

Later in early March 2020, IS Issued a Sharia Directives on the pandemic based on the al- Bukhari's collection of Hadess on Plague [10] and asked the followers of Islam to have trust in God and believe that the illness strikes only on the will of the Allah, and stay away from those infected with the virus. However, those who are in the infected areas must stay where they are and not leave the place and carry out attacks on the enemies of Islam. The newsletter al- Naba further said that those who die of the infection would be martyrs as the virus is a weapon of the apostate. He was chosen by God to fight against it. [11]

ISIS published a COVID-19 exclusive newsletter $\mathrm{Al}-\mathrm{Naba}$ (the Dispatch). The editorial was titled "The Crusaders' Worst Nightmare", discussing COVID-19's effect on the enemies of Islam whom ISIS collectively terms "polytheists", "apostates", and "infidels". [14] The editorial told its followers that the army of crusaders have become paralysed, and it is time for us to rebuild on our efforts. The editorial goes on to say that Satan's (referring to the US and its allied forces) are suffering for the sins they committed by entering Afghanistan and West 
Africa forcefully along with allies to exploit. [14]

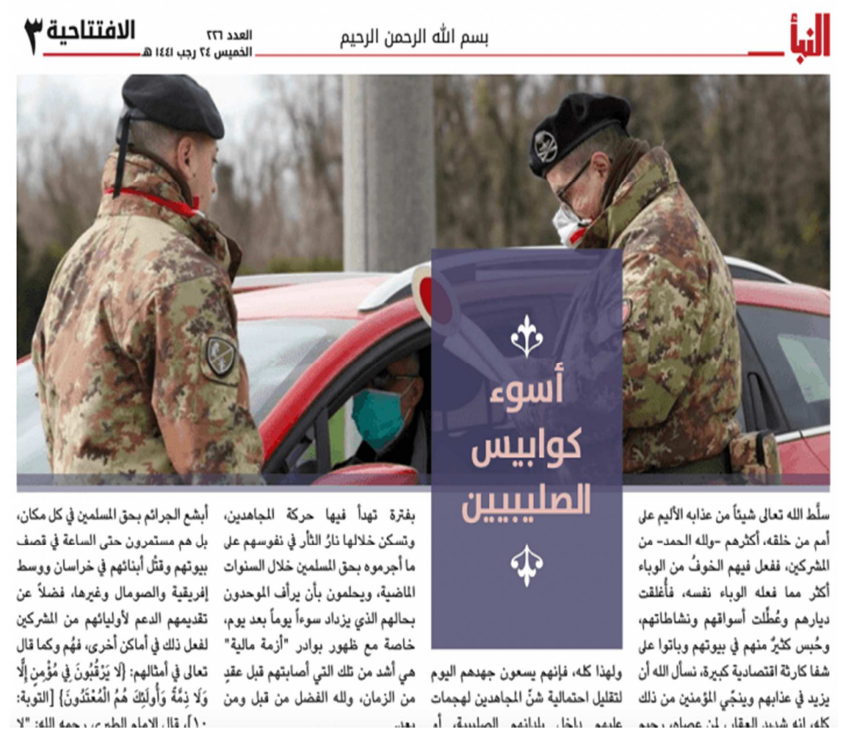

Figure 1. The ISIS newsletter al-Naba titled "The Crusaders' Worst Nightmare". [12-13]

Al-Naba concludes from the preceding that Muslims have a religious duty to shield their brethren's from the coronavirus and liberate Muslim captives from prisons and camps and show no mercy to the enemies. The editorial prompts readers that to avoid God's punishment- including coronavirus - is by doing jihad and inflict pain on His enemies. [14]

\section{The Exploitation of the Crisis Leading to Upsurge in the Attacks}

Several nations working in collaboration to defeat the terror groups in the region are announcing to pull down the strength of the troops or to restrict the movements of patrolling parties [15]. These pull-outs include troops from France in West Africa, Global Coalition to Defeat ISIS in Mali-Niger frontier. Covid-19 has threatened the cooperation amongst the US and France in places like Sahel region and Lake Chad Basin.

Because of the withdrawal and limitation of security forces, the rebels and terror groups have found an opportunity to flutter their wings and increase their footprint. As a result, more fighters are coming out to take charge of the supplies and services. The refugee camps have become a hub for the recruiters who are using the deprivation of necessities to their advantage in alluring them to pick up weapons.

These jihadists are exploiting the situation to propagate narratives- for example- in case the Covid cases increase in the Muslim majority areas; they will hold the west responsible for it. If in case the reverse of it happens then they have a chance to influence and convince people's mind that Allah saved its faithful followers. These rebels are informing people how the Christian missionaries will use pandemic and the gesture of aid giving to colonise the land and spread western values which is against the Islamic traditions.

\section{COVID-19 and Food Security Challenges}

The food security issue in Africa is multi-dimensional. It is a problem linked to healthcare, conflicts, policies, politics, environment and agricultural production.

The persisting lack of peace and security in many parts of Africa coupled with never-ending political instabilities and social crisis is mainly the reason for the failure of African countries in tackling the existential challenges and threats such as food security and widespread malnourishment.

\section{SAHEL AND WEST AFRICA: FOOD AND NUTRITION SITUATION}
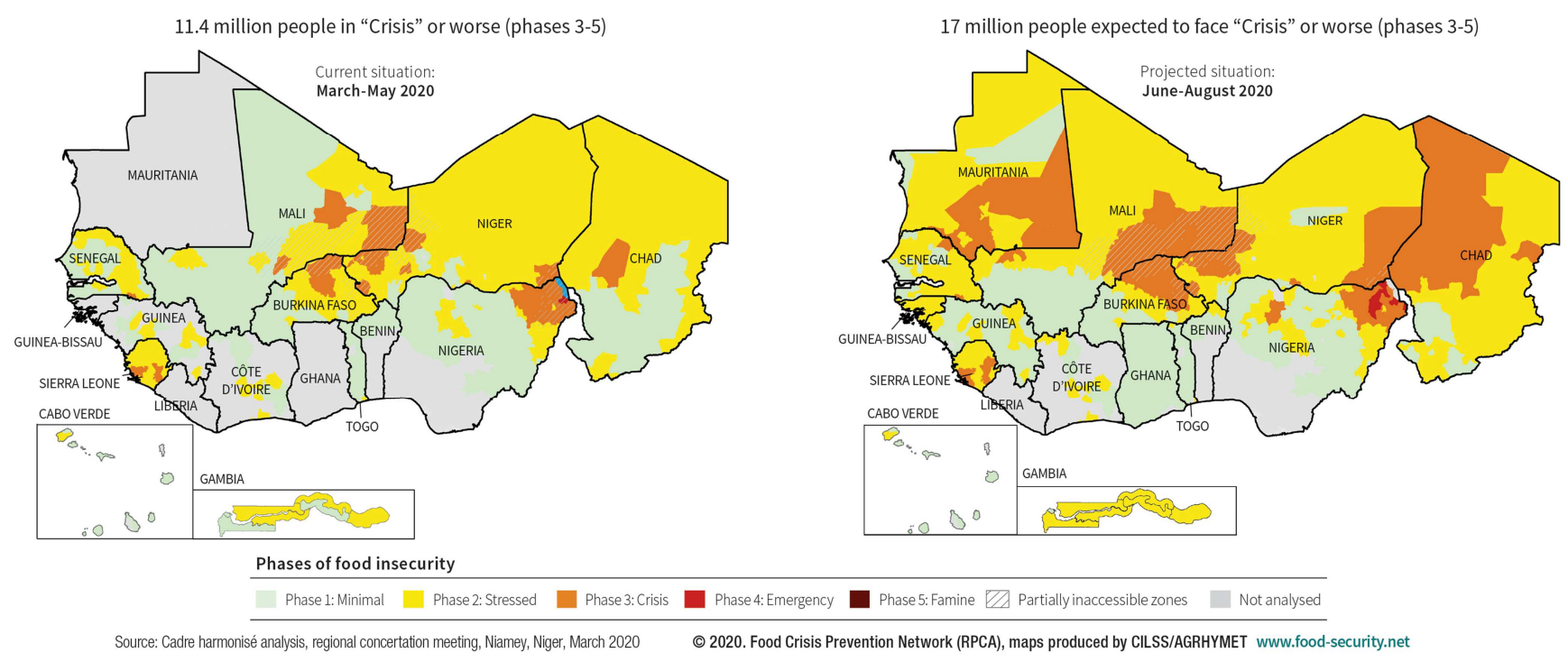

Figure 2. Sahel and West Africa: Food and Nutrition Situation from Phase 1-5. [16] 
are [17]:

1) Approximately 11.4 million people in the Sahel and West African region will require immediate assistance between March to May 2020.

2) By the June to August 2020, 17 million people are projected to be in a crisis or worse. It is more than the number which is usually affected in an average year.

3) The security crisis and the Covid-19 health crisis could tip over 51 million additional people into food and nutrition crisis.

4) Acute malnutrition persists throughout the region and affects nearly 2.5 million children under the age of 5 years in the Sahel region.

There are said to be multiple reasons for the predicted figures as per the report. The COVID-19 pandemic affects food systems directly through impacts on food supply and demand, supply chain disruptions, the possible collapse of local food systems but also indirectly through loss of incomes and employment, reduced social services [18]. Some of the prominent reasons are:

1) Locust attack- leading to a direct impact on the small scale farmers and daily wagers, food shortage and price rise in coming times, including black marketing and food control by the rebel groups.

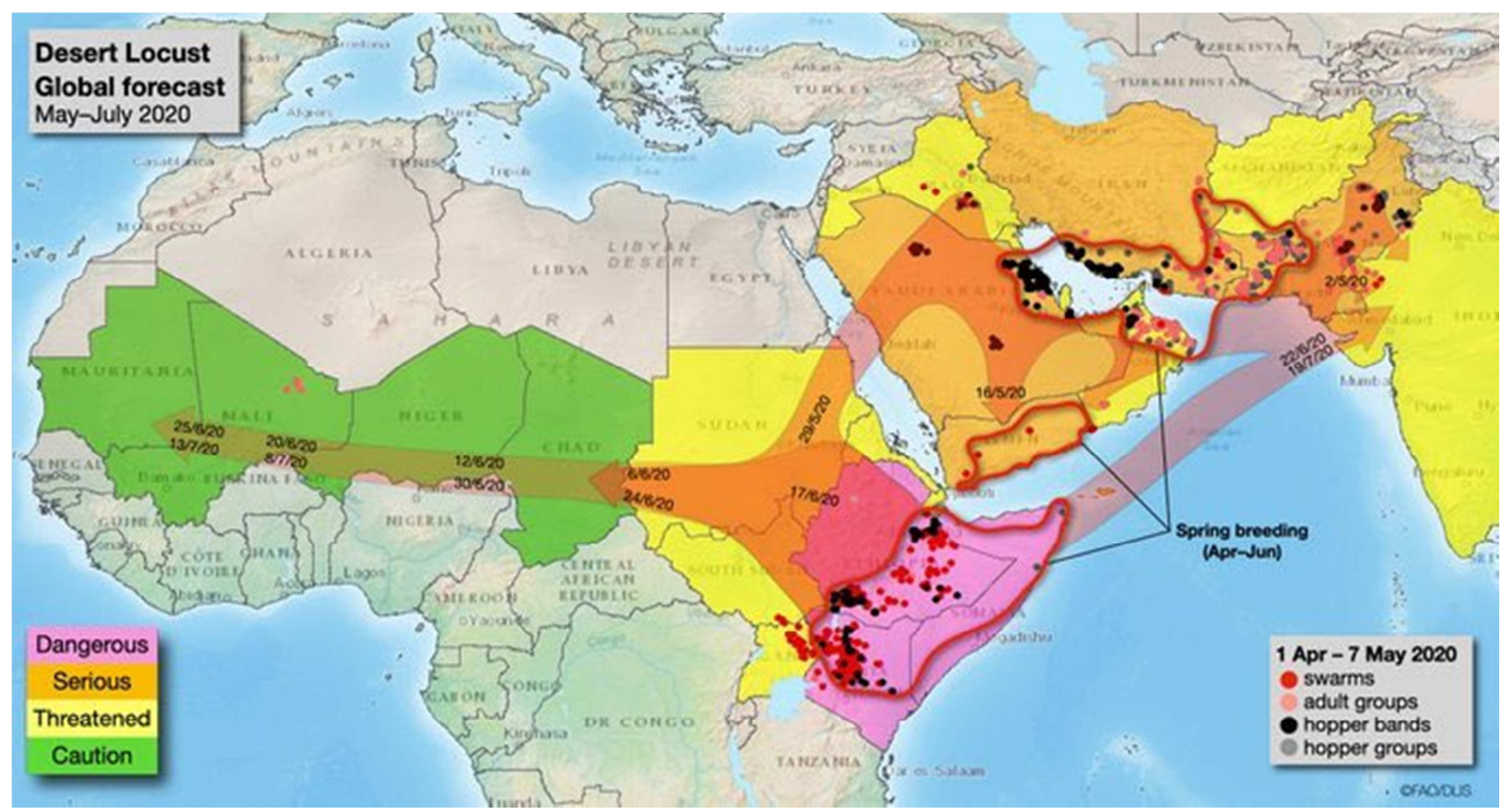

Figure 3. Locust Attack Tracking Map, Source: Twitter. [19]

2) Mobility restrictions and border closures- Timely delivery of urgent humanitarian and food assistance at risk. Preparation for the next agricultural season.

3) Curfews and lockdowns- significant income loss and increased unemployment numbers strongly impacting the urban food trade.

4) Market closures- increased difficulties to access food leading to nutrition deficits, disruption in supply chain causing the collapse of the food system, affecting farmers.

5) Global measures impacting local economies- sudden price rise in the imported food items due to the global lockdown and suspension of export and import business.

6) School closures affecting the nutrition of school children who were benefiting from the school meal plans.

\section{Way out of the Ongoing Issues in the Region}

As mentioned at the beginning of the article that problems in Africa are multi-dimensional, therefore the solution to the existing problem also needs to be multidimensional. Some of the options that can be explored by the stakeholders are:

1) Negotiation with all the religious and ethnic leaders to agree upon ceasefire appeal made by the UN Secretary-General. The regional political leaders must urge the rebel groups in the region to suspend all kinds of violent activities.

2) The international troop-contributing countries, and especially the United States, must not withdraw their troops from the African countries. In order to avoid the loss of the progress made in the fight against these rebel groups. The United States troops have been withdrawing troops as part of the 'global power competition' [20] with Russia, China, Iran and North Korea. However, Moscow has been increasing its arms deals in the region while China is building another military base in Senegal. The US must compete with China and Russia in Africa rather than opening another front.

3) Set up a Regional Task Force to monitor the trends of 
food security challenges. The priority should be to ensure containment of the malnutrition amongst the children under the age of five years. In phase 3 to 5 , (refer to figure 2) beginning from June, the challenge of food security will inflate. Therefore specific contingency plans can be chalked out to confront the environmental (locust attack) challenge.

4) Subsidised shops for affordable food items to reduce the chances of price rise and black marketing.

5) The internally displaced people (mostly the blue-collar workers) rehabilitated in the shelter camps providing them necessity items, followed by regular health screening to check for corona symptoms.

6) Outreach plans created for all those states which have been affected the most providing them basic meals and medical checkups. In all these initiatives, the ethnic, tribal, and rebel groups convinced to run the plan giving them a feeling of inclusivity and reduce the feeling of vengeance amongst themselves.

7) The farmers' loan could be waived off for the coming times to reduce the mental stress amongst the people. It will also reduce the increasing theft and conflict related to land and agriculture.

As rightly, said by the UN Secretary-General, the Covid-19 has yet not arrived in Africa. When it arrives, it is feared to cause irreparable damage to the nation. Therefore, all the national, regional and international stakeholders must continue supporting Africa in maintaining peace and security. To address the need of the hour, i.e., Covid-19, all the resources and powers must be used to ensure the least damage to its people.

\section{Conclusion}

Based on the evaluation, it can be assumed that the terror groups remain highly active in the Sahel Region of Africa. There are chances that the groups can have surge in power with the withdrawal of the United States troops from Africa.

COVID-19 has severely impacted the execution of safety measures, trial, reintegration efforts by the UN agencies. The series of corruption cases and incapability of the government officials has further worsened the situation and made it easy for the youth to get influenced by the terror groups.

The cyber space has become a new battlefield for sociopolitical warfare; the radical groups are actively using it for recruitment, information warfare, and radicalization. Especially, during the pandemic period, internet became the weapon in the hands of violent extremists who used it to spread abhorrence against the government and civil bodies.

The Author Certifies That

a. The article/paper is original in content, unpublished elsewhere and it has not been submitted for publication/web upload elsewhere.

b. Facts and figures quoted in the article/paper are duly referenced, as needed, and are believed to be correct.

\section{References}

[1] United Nations Press Release, Secretary-General Statements and Messages, ' Still Early Days for Pandemic in Africa, stressed Secretary-General, Warning Disruption could Escalate Quickly, on Launch of Covid-19 Policy Brief', United Nations https://www.un.org/press/en/2020/sgsm20090.doc.htm (Accessed May 20, 2020).

[2] Peter Mwai, 'Coronavirus: Africa infections rising sharply in worst-affected countries', BBC News, https://www.bbc.com/news/world-africa-53181555 (Accessed January 15, 2021).

[3] OECD, 'Tracking the Coronavirus (COVID-19): West African' Sahel and West Africa Club Secretariat Monitoring', http://www.oecd.org/swac/coronavirus-west-africa/ (Accessed January 10, 2021).

[4] African Centre for the Study \& Research on Terrorism, 'Africa Recorded a total of 195 terrorist attacks resulting in a total of 573 deaths', http://caert.org.dz/?p=3263 (Accessed December $29,2020)$.

[5] France 24 news, 'Burkina Faso struggles to tackle terror threat', https://www.france24.com/en/africa/20200424-reporters-burki na-faso-struggles-to-tackle-terror-threat (Accessed May 20, 2020)

[6] United Nations Secretary General, 'Secretary-General's Appeal for Global Ceasefire', New York, https://www.un.org/sg/en/content/sg/statement/2020-03-23/sec retary-generals-appeal-for-global-ceasefire (Accessed May 20, 2020).

[7] Suadad al-Salhy, 'Islamic States's 'Battle of Ramadan' rocks Iraq and stokes fears of resurgence', Middle East Eye, https://www.middleeasteye.net/news/islamic-state-iraq-ramad an-battle-insurgence-fears (Accessed May 20, 2020).

[8] The Jewish Voice, 'Battle of Ramadan: Jihadis kill 584, Injure 587 in Three Weeks of Holy Month', http://thejewishvoice.com/2020/05/battle-of-ramadan-jihadiskill-584-injure-587-in-three-weeks-of-holy-month/ (Accessed May 22, 2020).

[9] Beritbart, "Battle of Ramadan': Jihadis Kill 584, Injure 587 in Three Weeks of Holy Month', https://www.breitbart.com/national-security/2020/05/21/battle -of-ramadan-jihadis-kill-584-injure-587-in-three-weeks-of-hol y-month/ (Accessed May 21, 2020).

[10] Sunnah.com, 'Chapter 76 Medicines- Chapter What has been mentioned about the plague', https://sunnah.com/bukhari/76/43 (Accessed May 27, 2020).

[11] Aymenn Jawad Al- Tamimi, 'Islamic State Advice on Coronavirus Pandemic', http://www.aymennjawad.org/2020/03/islamic-state-advice-on -coronavirus-pandemic (Accessed May 19, 2020).

[12] Al Naba, 227, March 16, 2020 , https://d2071 andvip0wj.cloudfront.net/styles/image_medium/s 3/component/image/Al-Naba-ISIS-comm-3103.png?itok=asrk U780 (Accessed May 19, 2020).

[13] Nick Grono, 'Fragile States and Conflicts', Crisis Group, https://www.crisisgroup.org/global/contending-isis-time-coron avirus (Accessed May 18, 2020). 
[14] Jean-Marie Guehenno, 'Global Ceasefire Call Deserves UN Security Council's Full Support', https://www.crisisgroup.org/global/todays-global-security-chal lenges (Accessed May 20, 2020).

[15] Giles Gibson, 'Pentagon explores reducing U.S. military presence in West Africa', https://news.cgtn.com/news/2020-01-22/Pentagon-explores-re ducing-U-S-military-presence-in-West-Africa-NsbKUq836w/i ndex.html (Accessed May 23, 2020).

[16] The Food Crisis Prevention Network, 'Sahel and West Africa: Food and Nutrition Situation', http://www.food-security.net/wp-content/uploads/2020/04/CH -REGINAL_SAN_slider_2020_EN.gif (Accessed May 20, 2020).

[17] The Food Crisis Prevention Network, 'Food and Nutrition Crisis http://www.food-security.net/en/topic/food-and-nutrition-crisis $-2020 /($ Accessed, May 20, 2020).

[18] Patricia Rodrigues, 'Africa- no easy fix for food security challenges', Control Risks, https://www.controlrisks.com/our-thinking/insights/africa-no-e asy-fix-for-food-security-challenges (Accessed May 20, 2020).

[19] Map of Locust Attack track, Twitter, https://twitter.com/ParveenKaswan/status/1265126766131150 848/photo/1 (Accessed May 27, 2020).

[20] National Security Strategy of the United States of America', The White House, https://www.whitehouse.gov/wp-content/uploads/2017/12/NS S-Final-12-18-2017-0905-2.pdf (Accessed May 25, 2020). 